\title{
Indigofera adenotricha (Fabaceae: Faboideae), a new species from western Arnhem Land
}

\author{
Peter G. Wilson
}

\begin{abstract}
Wilson, Peter G. (National Herbarium of New South Wales, Royal Botanic Gardens, Sydney, NSW 2000, Australia) 2001. Indigofera adenotricha (Fabaceae: Faboideae), a new species from western Arnhem Land. Telopea 9(2): 353-355. A new species, Indigofera adenotricha, is described, illustrated and its a ffinities discussed; it is apparently restricted to western Arnhem Land in the Northern Territory, Australia. Although it seems to be a member of the sect. Viscosae, it does not appear to be closely related to the widespread I. colutea. I. adenotricha is distinguished from I. colutea by the plentiful, longer glandular hairs, the fewer and larger leaflets, the longer terminal leaflets and the pink-purple flowers.
\end{abstract}

\section{Introduction}

Three specimens of an Indigofera species, collected in the Northern Territory, have recently come to light that show a very distinctive combination of characters. Most noticeably, this plant has relatively long, gland-tipped hairs on all parts, rather reminiscent of the widespread species, I. colutea, but differs from the latter in many floral and pod characters. It is unlikely to be an introduction: Schrire (1995) lists the character-state 'multicellular gland-tipped hairs' as present in only two groups of species (one being sect. Viscosae, the Type of which is I. colutea) but this plant does not match the circumscription of any described species.

Indigofera adenotricha Peter G. Wilson, sp. nov.

Omnes partes pilis glandulosis numerosis instructa; folia pinnata foliolis plerumque 5-7, ellipticis, foliolo terminali quam ceteris manifeste longiore; inflorescentiae longae, folia excedentes; flores malvacei.

Holotype: Northern Territory: Darwin \& Gulf: East Alligator River, $4 \mathrm{~km} \mathrm{~S}$ of Cahills Crossing, Russell-Smith 570, 25 Apr 1983 (DNA).

[Indigofera sp. 1, Brennan (1996: 53)]

Spreading shrub, to $1 \mathrm{~m}$ high; young stems terete, covered with stalked glandular hairs $0.1-1 \mathrm{~mm}$ long, and scattered to dense, spreading, subequally biramous hairs. Leaves pinnate, (3-)5-7 leaflets; stipules linear, \pm persistent, 2-3 mm long and bearing biramous and glandular hairs; petiole 5-27 mm long; rachis furrowed, multicellular hairs between leaflet pairs absent. Leaflets opposite; stipellae absent or linear, 0.6-1.2 mm long; lamina elliptical to narrowly elliptical, the laterals (7.5-)9-17 mm long, 4.5-10.5 mm wide, the terminals $16-24(-28) \mathrm{mm}$ long, (5-)6.5-11.5 mm wide; upper surface greyish, with sparse to moderately dense, appressed to slightly spreading hairs and occasional shortly stalked glandular hairs; lower surface greenish, with scattered biramous hairs and frequent glandular hairs; apex acute to obtuse with a short mucro; veins not prominent. Inflorescences 120-230 mm long, longer than leaves; peduncle 14-24 mm long; bracts narrowly triangular to linear, $0.8-1.5 \mathrm{~mm}$ long; flowers pink to purple; pedicel c. $1 \mathrm{~mm}$ long. Calyx $2.5 \mathrm{~mm}$ long, with subequal to equal lobes equal to or 
longer than the length of the tube, clothed with moderately dense, white, spreading hairs with scattered glandular hairs (many sepals terminated by a gland). Standard pink-purple, broadly obovate to suborbicular, 5-6.5 $\mathrm{mm}$ high, 4-5.5 mm wide. Wings broadly obovate, 3.5-4 mm long, 1.5-2 mm wide. Keel c. $6 \mathrm{~mm}$ long, $2 \mathrm{~mm}$ deep; apex acute; lateral pockets c. $1 \mathrm{~mm}$ long; hairs sparse, hyaline, restricted to the bottom near the tip. Staminal tube 3-3.5 mm long, probably colourless. Ovary glabrous. Pod spreading to descending, terete, 16-18 mm long, 2.5-3 mm deep, brown, covered in gland-tipped hairs, with occasional spreading biramous hairs; apex shortly beaked or pointed; endocarp spotted. Seed 3-4 per fruit. (Fig. 1).

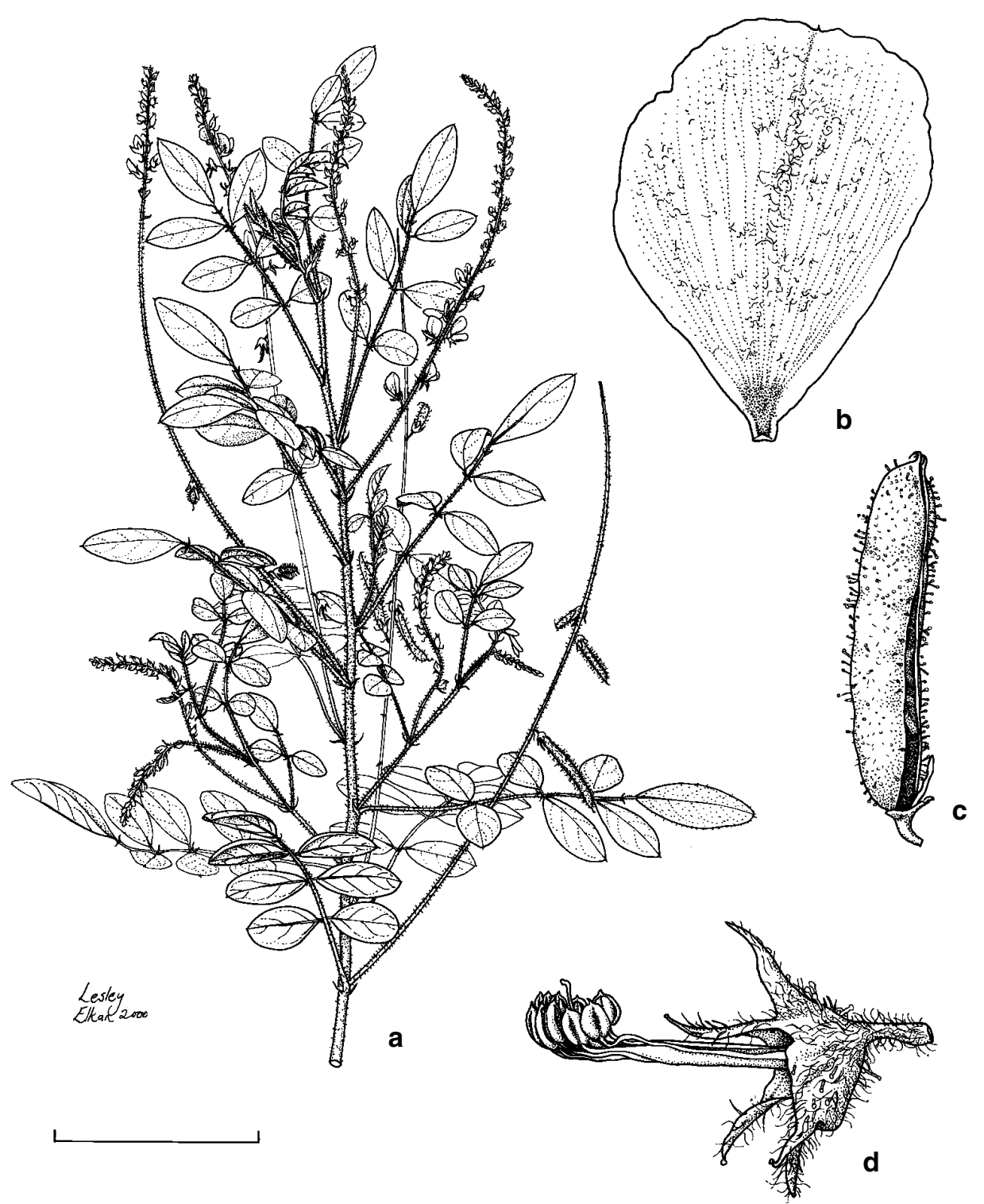

Fig. 1. Indigofera adenotricha. a, habit; b, standard; c, fruit; $\mathbf{d}$, lateral view of calyx and androecium. (a, b, d from Russell-Smith 570; c from Brennan 1370). Scale bar: $\mathrm{a}=40 \mathrm{~mm}$; $\mathrm{b}, \mathrm{d}=2.5 \mathrm{~mm} ; \mathrm{c}=10 \mathrm{~mm}$. 
Notes: despite the presence of stalked glands, this species does not appear to be very closely related to I. colutea; members of the group of species close to I. colutea have red flowers and narrow pods usually only up to $2 \mathrm{~mm}$ diam. (rarely to $2.5 \mathrm{~mm}$ ). This species is somewhat similar to I. scabrida, a glandular-haired species described from the province of Yunnan, China, but differs from that species in having pink to purple (rather than red) flowers, fewer leaflets and glandular (rather than glabrescent) pods. The plant is also notable for having rather long terminal leaflets, up to twice the length of the laterals. In this latter feature, it resembles another Northern Territory species, I. verruculosa, which also has pink to purple flowers; this species also has wart-like glands on its pods, stems and leaves, but these are sessile and non-viscid.

The epithet is derived from the Greek aden, adenos, gland, and thrix, trichos, hair, in reference to the stalked glands of this species.

Distribution and habitat: restricted to the Northern Territory (western part of Arnhem Land) where it is recorded from sandstone outcrops.

Conservation status: apparently uncommon, but conserved within Kakadu National Park. Staff from the Northern Territory herbarium, Darwin, searched for it in April/May 1999, but failed to find it and have suggested (C. Dunlop pers. comm.) that it may only appear after disturbance or fire.

Other specimens examined: Northern Territory: Darwin \& Gulf: c. $5 \mathrm{~km} \mathrm{~S}$ of Cahills Crossing, East Alligator River, Thompson 295, 25 Apr 1983 (CANB); on Bowerbird Track, near Magela Creek, Brennan 1370, 5 Aug 1991 (DNA).

\section{Acknowledgments}

I am indebted to Brian Schrire who very kindly confirmed the distinctness of this species, drew my attention to significant morphological features and suggested possible affinities. Thanks also to Clyde Dunlop and Ian Cowie for assistance in attempting to relocate this species and to Lesley Elkan for the excellent illustration.

\section{References}

Brennan, K. (1996) An Annotated Checklist of the Vascular Plants of the Alligator Rivers Region, Northern Territory, Australia. Supervising Scientist Report 109.

Schrire, B.D. (1995) Evolution of the tribe Indigofereae (Leguminosae Papilionoideae). Pp. 161-244 in Crisp, M.D. \& Doyle, J.J. (eds), Advances in Legume Systematics 7: Phylogeny. (Royal Botanic Gardens: Kew). 